\title{
Hydrolytic activity of human Nudt16 enzyme on dinucleotide cap analogs and short capped oligonucleotides
}

\author{
RENATA GRZELA, ${ }^{1}$ KAROLINA NASILOWSKA, ${ }^{2}$ MACIEJ LUKASZEWICZ, ${ }^{2}$ MICHAL TYRAS, ${ }^{1}$ JANUSZ STEPINSKI, \\ MARZENA JANKOWSKA-ANYSZKA, ${ }^{3}$ ELZBIETA BOJARSKA, ${ }^{1}$ and EDWARD DARZYNKIEWICZ ${ }^{1,2}$ \\ ${ }^{1}$ Centre of New Technologies, University of Warsaw, 02-097 Warsaw, Poland \\ ${ }^{2}$ Division of Biophysics, Institute of Experimental Physics, Faculty of Physics, University of Warsaw, 02-097 Warsaw, Poland \\ ${ }^{3}$ Faculty of Chemistry, University of Warsaw, 02-091 Warsaw, Poland
}

\begin{abstract}
Human Nudt16 (hNudt16) is a member of the Nudix family of hydrolases, comprising enzymes catabolizing various substrates including canonical (d)NTPs, oxidized (d)NTPs, nonnucleoside polyphosphates, and capped mRNAs. Decapping activity of the Xenopus laevis (X29) Nudt16 homolog was observed in the nucleolus, with a high specificity toward U8 snoRNA. Subsequent studies have reported cytoplasmic localization of mammalian Nudt16 with cap hydrolysis activity initiating RNA turnover, similar to Dcp2. The present study focuses on hNudt16 and its hydrolytic activity toward dinucleotide cap analogs and short capped oligonucleotides. We performed a screening assay for potential dinucleotide and oligonucleotide substrates for hNudt16. Our data indicate that dinucleotide cap analogs and capped oligonucleotides containing guanine base in the first transcribed nucleotide are more susceptible to enzymatic digestion by hNudt16 than their counterparts containing adenine. Furthermore, unmethylated dinucleotides (GpppG and ApppG) and respective oligonucleotides (GpppG-16nt and GpppA16nt) were hydrolyzed by $h N u d t 16$ with greater efficiency than were $m^{7} G p p p G$ and $m^{7} G p p p G-16 n t$. In conclusion, we found that hNudt16 hydrolysis of dinucleotide cap analogs and short capped oligonucleotides displayed a broader spectrum specificity than is currently known.
\end{abstract}

Keywords: decapping enzymes; nudix hydrolases; cap analogs; cap hydrolysis; capped oligonucleotides

\section{INTRODUCTION}

Eukaryotic mRNAs are modified with a covalently attached 7-methylguanosine cap at the $5^{\prime}$ end, with an unusual $5^{\prime}-5^{\prime}$ pyrophosphate bond (Furuichi and Shatkin 2000; Ghosh and Lima 2010). Cap hydrolysis is a critical step in mRNA turnover. mRNA decay can occur via two general pathways, in the $3^{\prime}-5^{\prime}$ or $5^{\prime}-3^{\prime}$ direction, both initiated by shortening of the poly(A) tail (Meyer et al. 2004). Therefore, different classes of decapping enzymes have been reported to function in these processes (Grudzien-Nogalska and Kiledjian 2017; Valkov et al. 2017). The $3^{\prime}$ end mRNA decay is carried out by a cytoplasmic multisubunit exosome complex (Schaeffer et al. 2009) and the resulting cap dinucleotides (or short oligonucleotides) are subsequently hydrolyzed by the scavenger decapping enzyme DcpS (Liu et al. 2002), which utilizes an evolutionarily conserved HIT motif to bind substrates and cleave the pyrophosphate bond within the cap, thereby releasing $\mathrm{m}^{7} \mathrm{GMP}$ (Liu et al. 2004). Cap removal from long

Corresponding authors: r.grzela@cent.uw.edu.pl, e.bojarska@cent.uw. edu.pl

Article is online at http://www.rnajournal.org/cgi/doi/10.1261/rna.065698. 118.
mRNAs in the $5^{\prime}-3^{\prime}$ decay pathway is carried out by two specific enzymes, Dcp2 and Nudt16, both members of the Nudix hydrolase superfamily, which hydrolyze various substrates composed of a nucleoside diphosphate linked to another moiety $\mathrm{X}$. Their catalytic activity depends on the highly conserved Nudix box within a sequence of 23 amino acids, $\mathrm{GX}_{5} \mathrm{EX}_{7} \mathrm{XREUXEEXGU}$, where $\mathrm{U}$ is a hydrophobic residue (usually Ile, Leu, or $\mathrm{Val}$ ), and $\mathrm{X}$ may be any residue (Bessman et al. 1996). This sequence is located in a loophelix-loop structural motif and the Glu residues within the core of the motif, REX2EE, are essential for binding divalent metal ions, $\mathrm{Mn}^{2+}$ or $\mathrm{Mg}^{2+}$ (Bessman et al. 1996). Nudix enzymes hydrolyze substrates usually through nucleophilic substitution at phosphorus, with variations in the type and number of divalent cations (Mildvan et al. 2005; McLennan 2006).

The most well characterized and widely conserved eukaryotic decapping enzyme is Dcp2, identified in yeast (Steiger

(c) 2018 Grzela et al. This article is distributed exclusively by the RNA Society for the first 12 months after the full-issue publication date (see http:// rnajournal.cshlp.org/site/misc/terms.xhtml). After 12 months, it is available under a Creative Commons License (Attribution-NonCommercial 4.0 International), as described at http://creativecommons.org/licenses/by-nc/4.0/. 
et al. 2003), nematodes (Cohen et al. 2005), plants (Iwasaki et al. 2007), and humans (Picirillo et al. 2003). Dcp2 cleaves $\mathrm{m}^{7} \mathrm{G}$-capped and $\mathrm{m}_{3}{ }^{2,2,7} \mathrm{G}$-capped RNAs, thereby releasing $\mathrm{m}^{7} \mathrm{GDP} / \mathrm{m}_{3}{ }^{2,2,7} \mathrm{GDP}$ and $5^{\prime}$ monophosphate RNA (Picirillo et al. 2003; Steiger et al. 2003; Cohen et al. 2005; Iwasaki et al. 2007). Dcp 2 recognizes mRNA by interacting with the cap structure and the RNA body (Deshmukh et al. 2008; Li et al. 2008), and preferentially utilizes RNAs longer than 25 nucleotides (nt). Its activity is tightly regulated by several proteins known to interact with Dcp2 in cytoplasmic foci called P-bodies (van Dijk et al. 2002; Franks and Lykke-Andersen 2008; Arribas-Layton et al. 2013). The presence of the second decapping enzyme Nudt16 has been reported in mammalian cells (Song et al. 2010; Lu et al. 2011). Nudt16 was initially identified in Xenopus as a U8 snoRNA decapping enzyme (termed as X29) (Ghosh et al. 2004; Peculis et al. 2007) and has also been proposed as a nucleolar decapping enzyme that is conserved in metazoans, but is absent in S. cerevisiae, C. elegans, and Drosophila (Taylor and Peculis 2008). Nudt16 orthologs were identified in 57 different organisms, both invertebrates and vertebrates (Trésaugues et al. 2015). Nudt16 distribution across metazoans implies an evolutionarily conserved biological role for this enzyme, which can cleave the $m^{7} G$ cap from pre-mRNA and mature mRNA prior to export, and the $\mathrm{m}_{3}{ }^{2,2,7} \mathrm{~A}$ cap from snRNA and snoRNA (Lange et al. 1998). Further studies revealed the abundance of hNudt16 in both the nucleus and cytoplasm (Song et al. 2010; Lu et al. 2011), demonstrating the pleiotropic decapping activity of this enzyme. Since its function partially overlaps with Dcp2 hydrolytic activity in mammalian cells, hNudt16 was proposed as the second decapping enzyme involved in the $5^{\prime} \rightarrow 3^{\prime}$ degradation of cytoplasmic mRNAs. Although both enzymes can initiate mRNA decay by hydrolyzing the cap structure, distinct roles for Dcp2 and Nudt16 in specific mRNA degradation pathways were reported ( $\mathrm{Li}$ et al. 2011). Nonsense-mediated mRNA decay is mostly mediated by Dcp2, while ARE-containing mRNAs and miRNA can be degraded by either Dcp2 or Nudt16.

A comparison of hNudt16 in vitro catalytic activity toward U8 snoRNA, luciferase mRNA, and influenza NP mRNA has shown similar decapping efficiency for these substrates ( $\mathrm{Lu}$ et al. 2011). The capability to cleave the cap from the three RNAs was very effective in the presence of $\mathrm{Mn}^{2+}$ and $\mathrm{Mg}^{2+}$, but drastically weaker with $\mathrm{Co}^{2+}$ and $\mathrm{Zn}^{2+}$. Interestingly, Nudt16 was also characterized as a "housecleaning" enzyme specialized in eliminating hazardous (deoxy)inosine diphosphate from the nuclear nucleotide pool (Iyama et al. 2010). The hydrolytic activity of recombinant hNudt16 was assessed in vitro with different purine nucleoside diphosphates (Trésaugues et al. 2015). Recent studies also reported that hNudt16 can process protein ADP-ribosylation (Daniels et al. 2015; Palazzo et al. 2015). The latest study (CarrerasPuigvert et al. 2017) analyzed human Nudix hydrolases on the basis of the deposited PDB structures and with numerous substrates, comprising standard and modified (deoxy)nucle- otides, adenine dinucleotide polyphosphates, nicotinamide adenine dinucleotides, or the standard $5^{\prime}$ cap. However, the cap structures, which are the subject of our study, were not investigated previously.

To further characterize the decapping activity of human Nudt16, we analyzed the substrate properties of several capped dinucleotides $\left(\mathrm{m}^{7} \mathrm{GpppG}, \mathrm{m}^{7} \mathrm{Gpppm}^{2^{\prime}-O} \mathrm{G}\right.$, $\mathrm{m}^{7} \mathrm{GpppA}, \mathrm{m}^{7} \mathrm{Gpppm} \mathrm{m}^{2^{\prime}-O} \mathrm{~A}$, and $\mathrm{m}_{3}{ }^{2,2,7} \mathrm{GpppG}$ ) and short oligonucleotides ( $\mathrm{m}^{7} \mathrm{GpppG}-16 \mathrm{nt}, \mathrm{m}^{7} \mathrm{Gpppm}{ }^{2^{\prime}-O} \mathrm{G}-16 \mathrm{nt}$, $\mathrm{m}^{7}$ GpppA-16nt, $\mathrm{m}^{7}$ Gpppm ${ }^{2}-\mathrm{O}$ A-16nt $\mathrm{m}^{7}$ GpppG-34nt, and $\left.\mathrm{m}^{7} \mathrm{Gpppm}^{2^{\prime}-O} \mathrm{G}-34 \mathrm{nt}\right)$. Simultaneously, we also analyzed unmethylated dinucleotides (GpppG, ApppG) and their oligonucleotide counterparts (GpppG-16nt, GpppA-16nt, and GpppG-34nt). Analysis of hNudt16 hydrolysis of dinucleotide cap analogs and short capped oligonucleotides displayed a much broader spectrum for enzyme specificity than is currently known.

\section{RESULTS}

\section{Hydrolytic activity of hNudt16 on dinucleotides}

Human Nudt16 is known to display activity toward various mononucleotides and long RNAs (Ghosh et al. 2004; Peculis et al. 2007; Taylor and Peculis 2008; Iyama et al. 2010; Song et al. 2010; Li et al. 2011; Lu et al. 2011; Trésaugues et al. 2015). In the present study, we investigated the hydrolytic activity of hNudt16 on dinucleotides and short oligonucleotides. Initially, we performed an activity screening assay to identify potential dinucleotide substrates for this hNudt16. The hydrolytic reactions of several dinucleotides (GpppG, ApppG, $\mathrm{m}^{7} \mathrm{GpppG}, \mathrm{m}^{7} \mathrm{Gpppm}^{2^{\prime}-O} \mathrm{G}$, $\mathrm{m}^{7} \mathrm{Gpppm} \mathrm{m}^{7} \mathrm{G}, \mathrm{m}^{7} \mathrm{GpppA}, \mathrm{m}^{7} \mathrm{Gpppm}^{2^{\prime}-O} \mathrm{~A}$, and $\left.\mathrm{m}_{3}^{2,2,7} \mathrm{GpppG}\right)$ (Fig. 1) catalyzed by hNudt16 were studied under the same experimental conditions (substrate and enzyme concentration, buffer composition, and temperature), which allowed for direct comparison of their hydrolytic susceptibilities. Reaction progress was monitored through HPLC analysis. Reduction in chromatographic peaks corresponding to the substrate was accompanied by the peaks characteristic of hydrolysis products (Fig. 2). The results of all investigated compounds are summarized in Table 1. Our data indicate that dinucleotide cap analogs containing guanine base in the first transcribed nucleotide are more susceptible to enzymatic digestion by hNudt16 than their counterparts containing adenine. $\mathrm{m}^{7} \mathrm{GpppG}, \mathrm{m}^{7} \mathrm{Gpppm} \mathrm{m}^{2^{\prime}-\mathrm{O}} \mathrm{G}$, and $\mathrm{m}_{3}{ }^{2,2,7} \mathrm{GpppG}$ were hydrolyzed by hNudt16 with a comparable rate. After $100 \mathrm{~min}$ of incubation with hNudt16 $(0.9 \mu \mathrm{M}$ in reaction mixture), approximately $75 \%$ of $\mathrm{m}^{7} \mathrm{GpppG}$ and $\mathrm{m}^{7} \mathrm{Gpppm}^{2^{\prime}-O} \mathrm{G}$ were converted to $\mathrm{m}^{7} \mathrm{GDP}$ and $\mathrm{GMP} / \mathrm{m}^{2^{\prime}-O}$ GMP, respectively. $m^{7}$ GpppA and $m^{7}$ Gpppm ${ }^{2}-O$ A seemed less susceptible to enzymatic cleavage. A small proportion of those compounds were hydrolyzed simultaneously during incubation with the enzyme. Unmethylated dinucleotides, GpppG and ApppG, were also hydrolyzed by hNudt16, albeit 

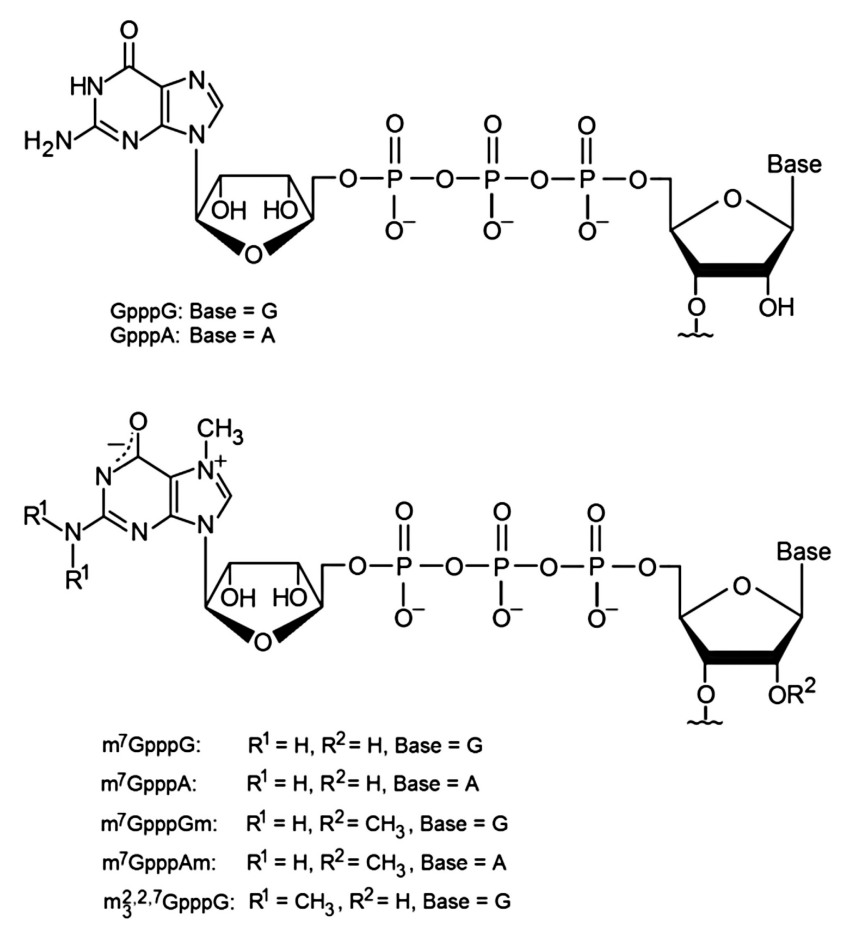

Figure 1. Structures of the dinucleotides used in the present study.

with greater efficiency than for $\mathrm{m}^{7} \mathrm{GpppG}$ and $\mathrm{m}^{7} \mathrm{Gpppm} \mathrm{2}^{2^{\prime}-\mathrm{O}} \mathrm{G}$. However, no hydrolysis products were detected for $\mathrm{m}^{7} \mathrm{Gpppm}^{7} \mathrm{G}$.

\section{Hydrolytic susceptibility of capped oligonucleotides to hNudt16-mediated hydrolysis}

Further, we analyzed the hydrolytic susceptibility of short oligonucleotides capped with the same aforementioned dinucleotides. These oligonucleotides were transcribed in vitro and incubated with recombinant hNudt16 to initiate the decapping process. At different time points $(5,15,30,60$, and $180 \mathrm{~min}$, and $24 \mathrm{~h}$ ), enzymatic reactions were terminated and the reaction mixtures were analyzed on a sequencing gel, stained with a fluorescent dye, and visualized using a UV-transilluminator. Levels of decapped transcripts were determined through densitometric analysis. The results of decapping of GpppG-16nt and $\mathrm{m}^{7} \mathrm{GpppG}-16 \mathrm{nt}$ are presented in Figure 3A-C. In both cases, the capped oligonucleotides (marked with C) migrate slower than the decapped products (marked with D). Bands migrating above the capped bands resulted from the inherent ability of T7 polymerase to transcribe certain oligonucleotides containing one or more additional nontemplate nucleotides at the $3^{\prime}$ end (Milligan et al. 1987). There was also a small amount of decapped product at time 0 , increasing from incomplete capping during in vitro transcription which hardly ever is $100 \%$ efficient. During the first $15 \mathrm{~min}$ of the reaction, GpppG-16nt was hydrolyzed twofold more efficiently than $\mathrm{m}^{7} \mathrm{GpppG}-16 \mathrm{nt}$; however, after a longer duration $(1 \mathrm{~h})$, the extent of decapped products was similar for both transcripts. The same effect was observed for $\mathrm{m}_{3}^{2,2,7}$ GpppG-16nt (Fig. 3B,C).

The results of hydrolysis of all investigated oligonucleotides are summarized in Table 2. Our data indicate similar decapping efficiency for transcripts with $\mathrm{m}^{7} \mathrm{GpppG}$, $\mathrm{m}^{7} \mathrm{Gpppm}{ }^{2^{\prime}-\mathrm{O}} \mathrm{G}$, and $\mathrm{m}_{3}^{2,2,7} \mathrm{GpppG}$. Approximately $80 \%$ of the three compounds was hydrolyzed during $60 \mathrm{~min}$. Transcripts containing $\mathrm{m}^{7} \mathrm{GpppA}$ and $\mathrm{m}^{7} \mathrm{Gpppm}^{2^{\prime}-\mathrm{O}} \mathrm{A}$ underwent cap cleavage at a significantly lower rate. During $60 \mathrm{~min}$ of the reaction, only $5 \%$ of both substrates were hydrolyzed and $50 \%$ of decapping was achieved after a prolonged duration $(24 \mathrm{~h})$ of incubation. Interestingly, GpppG-16nt and GpppA-16nt oligonucleotides proved to be more susceptible to enzymatic cleavage by hNudt 16 than their methylated counterparts. A significant difference was observed at the initial stage of hydrolysis (15 min); however, after a longer duration (60 min), the extent of decapping was comparable for all transcripts.

Analysis of the hydrolysis of longer transcripts (GpppG34nt, $\mathrm{m}^{7}$ GpppG-34nt, $\mathrm{m}^{7}$ Gpppm ${ }^{2^{\prime}-\mathrm{O}} \mathrm{G}-34 \mathrm{nt}$ ) (Fig. 3D) indicates the same tendency, as observed for dinucleotides and short oligonucleotides (16 nt). As shown in Table 2, decapping efficiency determined at different time points of the reaction is nearly equal for transcripts $\mathrm{m}^{7} \mathrm{GpppG}-34 \mathrm{nt}$ and $\mathrm{m}^{7} \mathrm{Gpppm}^{2^{\prime}-O} \mathrm{G}-34 \mathrm{nt}$, but significantly higher for GpppG34nt. During the first $5 \mathrm{~min}$ of hydrolysis, approximately $50 \%$ of unmethylated transcript GpppG-34nt was hydrolyzed. Simultaneously, only a small proportion of methylated oligonucleotides was decapped, although the enzyme levels in the reaction mixture were fivefold higher. Hydrolysis was more efficient for transcripts containing $16 \mathrm{nt}$ than for their counterparts containing $34 \mathrm{nt}$.

The results obtained for oligonucleotides are concurrent with those for dinucleotides, indicating the crucial role of guanine base in the first transcribed nucleotide for efficient decapping by hNudt16. However, the difference in decapping efficiency between methylated and unmethylated species was most significant for transcripts containing $34 \mathrm{nt}$.

\section{Hydrolysis of capped oligonucleotides catalyzed by the Dcp1/Dcp2 complex}

Selected oligonucleotides ( $\mathrm{m}^{7} \mathrm{GpppG}-16 \mathrm{nt}, \mathrm{m}^{7} \mathrm{GpppG}-$ $34 \mathrm{nt}$, and $\left.\mathrm{m}^{7} \mathrm{Gpppm}^{2^{\prime}-\mathrm{O}} \mathrm{G}-34 \mathrm{nt}\right)$ were hydrolyzed by the Schizosaccharomyces pombe Dcp1/Dcp2 complex. Electrophoresis and evaluation of hydrolysis efficiency obtained through densitometric analysis are shown in Figure 3. Our data indicate that $\mathrm{m}^{7} \mathrm{GpppG}-34 \mathrm{nt}$ and $\mathrm{m}^{7} \mathrm{Gpppm}{ }^{2^{\prime}-O} \mathrm{G}-34 \mathrm{nt}$ rather than $\mathrm{m}^{7} \mathrm{GpppG}-16$ nt were hydrolyzed more efficiently by Dcp1/Dcp2. According to the current literature, Dcp2 can hydrolyze capped transcripts that are at least $26 \mathrm{nt}$ long (Scarsdale et al. 2006). Our results are concurrent with the published data. In our experiments, longer transcripts (GpppG-34nt, $\mathrm{m}^{7} \mathrm{GpppG}-34 \mathrm{nt}$, and 


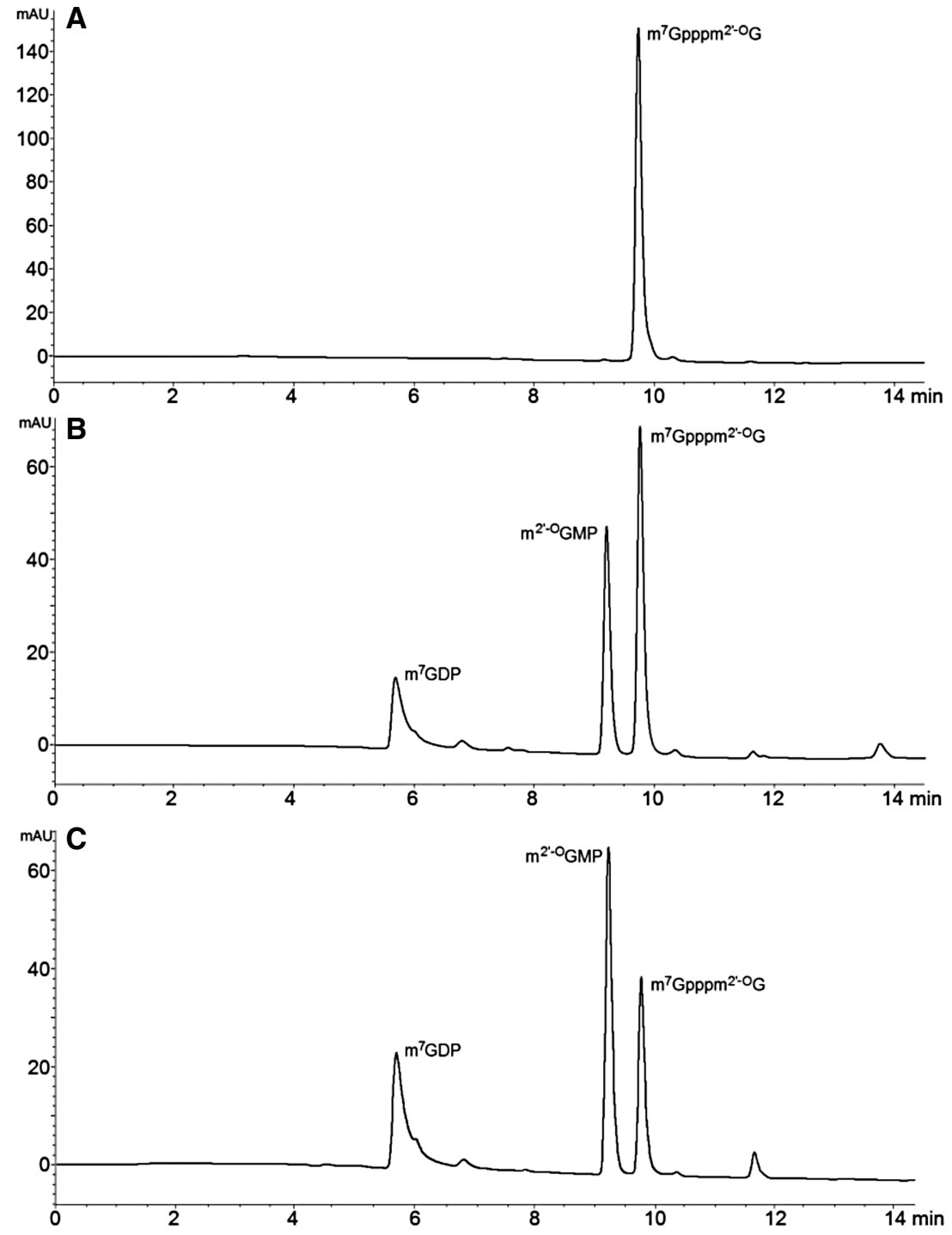

Figure 2. HPLC profiles of $\mathrm{m}^{7} \mathrm{Gpppm}{ }^{2^{\prime}-O} \mathrm{G}$ hydrolyzed with recombinant hNudt16: $(A)$ before hydrolysis, $(B)$ after 60 min of hydrolysis, $(C)$ after $100 \mathrm{~min}$ of hydrolysis. Reaction was performed at $37^{\circ} \mathrm{C}$, in $40 \mathrm{mM}$ Tris buffer ( $\mathrm{pH} 7.9$ ) containing $100 \mathrm{mM} \mathrm{NaCl}, 6 \mathrm{mM} \mathrm{MgCl}$, and 2 mM DTT.

$\left.\mathrm{m}^{7} \mathrm{Gpppm}^{2^{\prime}-\mathrm{O}} \mathrm{G}-34 \mathrm{nt}\right)$ were mostly hydrolyzed during $5 \mathrm{~min}$ of incubation with the enzyme, whereas the shorter one ( $\mathrm{m}^{7} \mathrm{GpppG}$-16nt) was hydrolyzed only to a small extent after 60 min of incubation with the enzyme. Dcp1/Dcp2 levels in the reaction mixture were $50 \mathrm{nM}$, approximately 400 times lower than those of hNudt16 $(18 \mu \mathrm{M})$ in reactions with the same substrates. This comparison indicates much higher catalytic efficiency of the Dcp1/Dcp2 complex toward capped oligonucleotides than of hNudt16.

\section{DISCUSSION}

The Nudix family of hydrolases comprises numerous enzymes with various functions. Many of them catabolize various substrates including canonical (d)NTPs, oxidized (d)NTPs, non-nucleoside polyphosphates, and capped mRNAs (Mildvan et al. 2005). The present study focused on hNudt16 and its hydrolytic activity toward dinucleotide cap analogs and short capped oligonucleotides. Previously, it was reported that this enzyme has mRNA decapping activity; however, the diversity of naturally occurring cap structures was not addressed. Hence, we investigated several dinucleotide cap analogs as potential substrates of this enzyme. Our results confirmed the previously reported data that hNudt16 hydrolyzes the dinucleotide cap analog $\mathrm{m}^{7} \mathrm{GpppG}$, yielding $\mathrm{m}^{7} \mathrm{GDP}$ and GMP (Song et al. 2010). Moreover, we report that the other cap analogs containing additional methylations and bearing guanine base in the first transcribed nucleotide $\left(\mathrm{m}^{7} \mathrm{Gpppm}^{2^{\prime}-\mathrm{O}} \mathrm{G}\right.$ and $\mathrm{m}_{3}^{2,2,7} \mathrm{GpppG}$ ) were also hydrolyzed by hNudt16, with an efficiency comparable to that for $\mathrm{m}^{7} \mathrm{GpppG}$ hydrolysis. In contrast, cap analogs with adenine $\left(\mathrm{m}^{7} \mathrm{GpppA}\right.$ and $\left.\mathrm{m}^{7} \mathrm{Gpppm}^{2^{\prime}-\mathrm{O}} \mathrm{A}\right)$ were significantly less susceptible to enzymatic cleavage. These data were unexpected, as the previously reported crystal structure of Xenopus laevis Nudt16 with $\mathrm{m}^{7}$ GpppA dinucleotide displayed binding via the adenine part of the cap, while $\mathrm{m}^{7} \mathrm{G}$ protruded outward with little or no interaction with the protein (Fig. 4; Scarsdale et al. 2006). Notably, depending on the identity of the base, nucleosides adopt an anti or syn conformation for guanosine and adenosine, respectively, upon binding, probably because the protein's capacity to bind the adenine-containing compounds was preserved in the conformation that prevents hydrolysis.

Our results show that dinucleotides methylated at the N(7) position of guanine are worse substrates for hNudt16. Moreover, in the case of $\mathrm{m}^{7} \mathrm{GpppG}$ and GpppG, we observed the release of $\mathrm{m}^{7} \mathrm{GDP}$ and GDP, respectively; however, only GDP was rapidly converted to GMP. We also assessed the two-headed $\mathrm{m}^{7} \mathrm{Gpppm}{ }^{7} \mathrm{G}$ dinucleotide, which proved to be resistant to hydrolysis, thereby indicating that Nudt 16 cannot hydrolyze N(7)-methylated substrates. Investigation of the crystal structure of GTP-bound Nudt16 suggests the possibility of there being enough space to accommodate $\mathrm{m}^{7} \mathrm{G}$, as $\mathrm{N}(7)$ has no direct interaction with the protein side chains, but the positive charge at the methylated $\mathrm{N}(7)$ position may negatively impact binding, thereby inhibiting hydrolysis. 
Table 1. Hydrolysis of dinucleotide cap analogs catalyzed by recombinant hNudt16

\begin{tabular}{|c|c|c|c|c|c|c|c|}
\hline \multirow[b]{2}{*}{ Dinucleotide } & \multicolumn{7}{|c|}{$\%$ of hydrolyzed dinucleotide after indicated time of reaction } \\
\hline & $10 \mathrm{~min}$ & $20 \mathrm{~min}$ & $30 \mathrm{~min}$ & $40 \mathrm{~min}$ & $60 \mathrm{~min}$ & $80 \mathrm{~min}$ & $100 \mathrm{~min}$ \\
\hline GрppG & $42.67 \pm 3.28$ & $66.47 \pm 2.89$ & $83.35 \pm 4.04$ & $98.79 \pm 6.11$ & - & - & - \\
\hline ApppG & $24.67 \pm 3.34$ & $43.11 \pm 4.82$ & $55.04 \pm 8.02$ & $62.94 \pm 3.66$ & $75.71 \pm 5.85$ & $86.87 \pm 7.44$ & $94.32 \pm 11.22$ \\
\hline $\mathrm{m}^{7} \mathrm{GpppG}$ & $17.63 \pm 1.28$ & $29.44 \pm 3.73$ & $39.67 \pm 5.34$ & $45.18 \pm 4.98$ & $54.36 \pm 7.12$ & $67.43 \pm 8.15$ & $72.97 \pm 9.48$ \\
\hline $\mathrm{m}^{7} \mathrm{Gpppm}{ }^{2^{\prime}-O} \mathrm{G}$ & $17.55 \pm 3.05$ & $29.77 \pm 6.24$ & $37.08 \pm 4.99$ & $43.98 \pm 8.21$ & $56.77 \pm 5.72$ & $69.24 \pm 7.99$ & $76.89 \pm 8.77$ \\
\hline $\mathrm{m}_{3}^{2.2 .7} \mathrm{GpppG}$ & $10.74 \pm 1.89$ & $20.71 \pm 3.05$ & $27.18 \pm 5.89$ & $33.73 \pm 7.39$ & $46.64 \pm 9.56$ & $57.23 \pm 10.56$ & $64.96 \pm 11.27$ \\
\hline $\mathrm{m}^{7} \mathrm{GpppA}$ & nd & nd & nd & nd & nd & nd & $2.57 \pm 0.45$ \\
\hline $\mathrm{m}^{7} \mathrm{Gpppm} \mathrm{m}^{2^{\prime}-O} \mathrm{~A}$ & nd & nd & nd & nd & nd & nd & $1.68 \pm 0.32$ \\
\hline $\mathrm{m}^{7} \mathrm{Gpppm}^{7} \mathrm{G}$ & nd & nd & nd & nd & nd & nd & nd \\
\hline
\end{tabular}

Reactions were performed at $37^{\circ} \mathrm{C}$, in $40 \mathrm{mM}$ Tris buffer ( $\mathrm{pH}$ 7.9) containing $100 \mathrm{mM} \mathrm{NaCl}, 6 \mathrm{mM} \mathrm{MgCl}$, and $2 \mathrm{mM}$ DTT. Dinucleotide concentration was $15 \mu \mathrm{M}$, enzyme concentration $0.9 \mu \mathrm{M}$. The extent of decapping was determined as the percentage of hydrolyzed dinucleotide measured by HPLC method (based on the three independent experiments for each compound). (nd, not detected.)

Interestingly, both unmethylated cap analogs, GpppG and ApppG, were hydrolyzed more efficiently than canonical $\mathrm{m}^{7} \mathrm{GpppG}$ cap. Since the unmethylated dinucleotide cap structure is symmetrical, it can be accessed from either side by Nudt16. In the case of ApppG, we observed a slight delay in hydrolysis, which can probably be explained by the exclusive cap dinucleotide hydrolysis from the guanosine end.

We also found that hNudt16 can recognize short capped oligonucleotides (16 nt and $34 \mathrm{nt}$ ) as substrates. In the case of 16-nt oligonucleotides, we observed an even stronger preference for unmethylated cap structures. Similarly to dinucleotides, additional methyl groups in $\mathrm{m}^{7} \mathrm{Gpppm}^{2^{\prime}-\mathrm{O}} \mathrm{G}-$ and $\mathrm{m}_{3}{ }^{2,2,7} \mathrm{GpppG}$-capped oligonucleotides did not affect rate of the hydrolysis. Furthermore, oligonucleotides containing adenine in the first nucleotide were also processed significantly slower than corresponding substrates with guanine. Considering structures of oligonucleotides, we expected only the external $\left(\mathrm{m}^{7}\right) \mathrm{Gppp}$ region of the cap to be accessible by Nudt16. Nevertheless, we are unsure whether hydrolysis can occur via binding of the proximal $\left(\mathrm{m}^{7} \mathrm{Gpp}\right)$, distal (ppG/ppA), or either region of the cap. The observation that unmethylated cap structures in GpppG-16nt and GpppA-16nt are hydrolyzed at a similar rate contrasts that of their $m^{7} G$ counterparts, wherein one can see a clear preference for $\mathrm{m}^{7} \mathrm{GpppG}-16 \mathrm{nt}$ over $\mathrm{m}^{7} \mathrm{GpppA}$-16nt. We also observed an additional product of GpppG-16nt and GpppA16nt hydrolysis, which migrated between the capped and uncapped RNA species (Fig. 3), which could have resulted from alternative cap cleavage resulting in a mixture of pG-16nt and ppG-16nt (and their adenine counterparts). However, no such products were observed in the case of methylated $\mathrm{m}^{7}$ GpppG-16nt and $\mathrm{m}^{7}$ GpppA-16nt oligonucleotides, which in turn suggests that methylation at the $\mathrm{N}(7)$ position prevents $\mathrm{m}^{7} \mathrm{G}$ binding, and the enzyme recognizes only the first transcribed nucleotide. Consequently, hydroly- sis of oligonucleotides leads to the generation of exclusively $\mathrm{m}^{7} \mathrm{GDP}$ and $\mathrm{pA}-16 \mathrm{nt} / \mathrm{pG}-16 \mathrm{nt}$.

A significant effect of adenosine on hydrolysis was unexpected, considering that Nudt16 was initially found to cleave the hypermethylated cap bound to adenosine $\left(\mathrm{m}_{3}{ }^{2,2,7} \mathrm{GpppA}\right)$ present at the $5^{\prime}$ end of U8 snoRNA (Lange et al. 1998). It is, however, notable that Nudt16 binds U8 snoRNA regardless of the presence of the cap structure, thus indicating the possible importance of RNA secondary structures that can interact with the cationic surface of the protein.

Hydrolytic activity toward the dinucleotide cap structures in cells is attributed to the scavenger decapping enzyme (DcpS), which is involved in the last step of the $3^{\prime} \rightarrow 5^{\prime}$ mRNA degradation pathway. hNudt16 can also hydrolyze dinucleotide cap analogs; however, its activity toward $\mathrm{m}^{7} \mathrm{GpppG}$ is significantly lower than that observed for hDcpS (Song et al. 2010). Substrate specificity of hNudt16 is also different from that of $\mathrm{hDcpS}$. The preferred substrate for hDcpS is $\mathrm{m}^{7} \mathrm{GpppG}$, while GpppG is hydrolyzed less efficiently and $\mathrm{m}_{3}^{2,2,7} \mathrm{GpppG}$ is resistant to hydrolysis by this enzyme. In contrast, hNudt 16 hydrolyzes $\mathrm{m}^{7} \mathrm{GpppG}$ and $\mathrm{m}_{3}{ }^{2,2,7} \mathrm{GpppG}$ with comparable rates; however, it hydrolyzes unmethylated dinucleotides, GpppG and ApppG, more efficiently. We also compared decapping activities of hNudt 16 toward $m^{7}$ GpppG-34nt and $m^{7} G_{p p p m}{ }^{2}-O$ G-34nt with that of Dcp2. For both transcripts, decapping efficiency was significantly higher in the presence of Dcp2. Nonetheless, none of these enzymes can hydrolyze oligonucleotides longer than $10 \mathrm{nt}$ and shorter than $25 \mathrm{nt}$. However, it is unclear whether hNudt16 has an additional role in the mRNA decapping process. If such a role is biologically significant, hNudt 16 activity would be enhanced by an unknown partner protein. However, it is more probable that hNudt16 is engaged in cellular functions other than RNA decapping. Moreover, hNudt6 was reported to hydrolyze several other purine nucleoside diphosphates and cleave pyrophosphate 
A

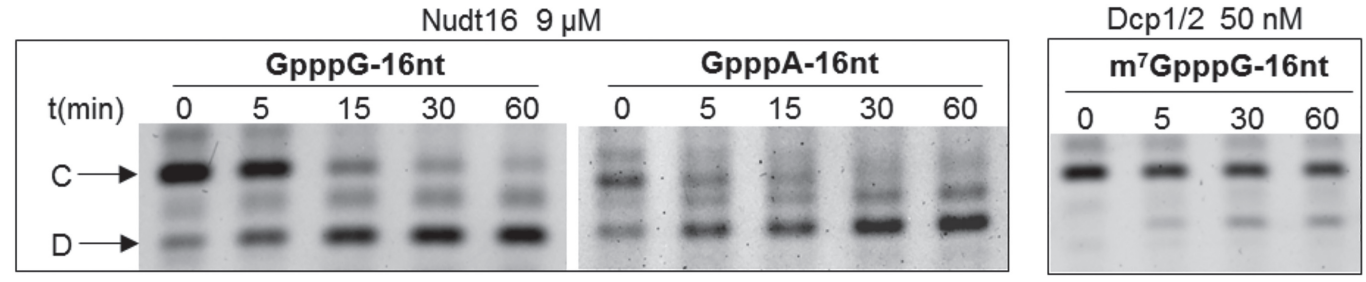

B Nudt16 $18 \mu \mathrm{M}$

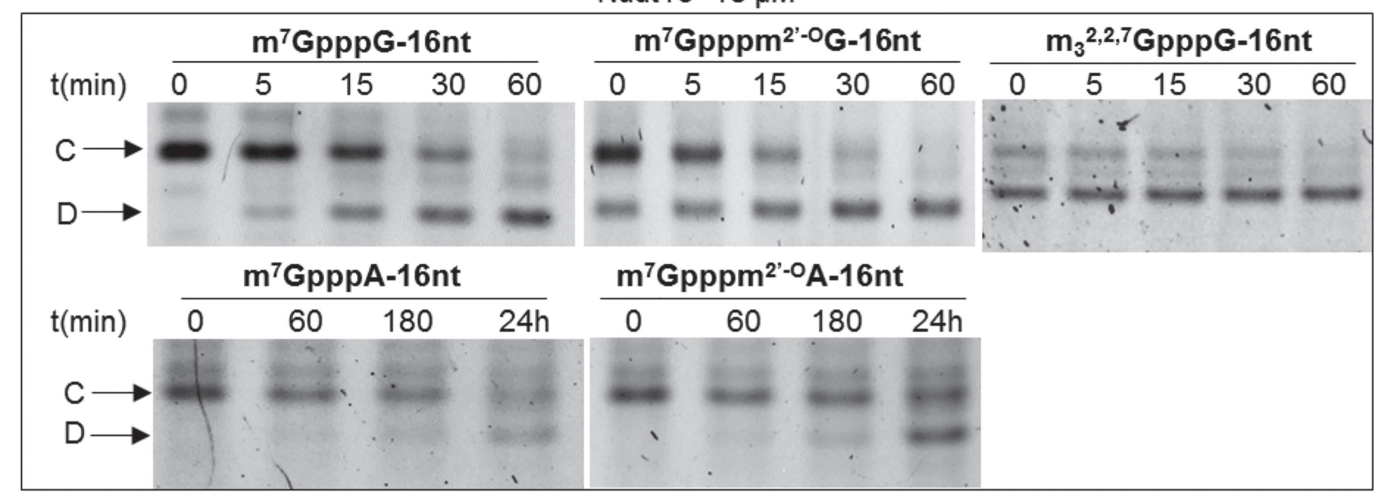

C
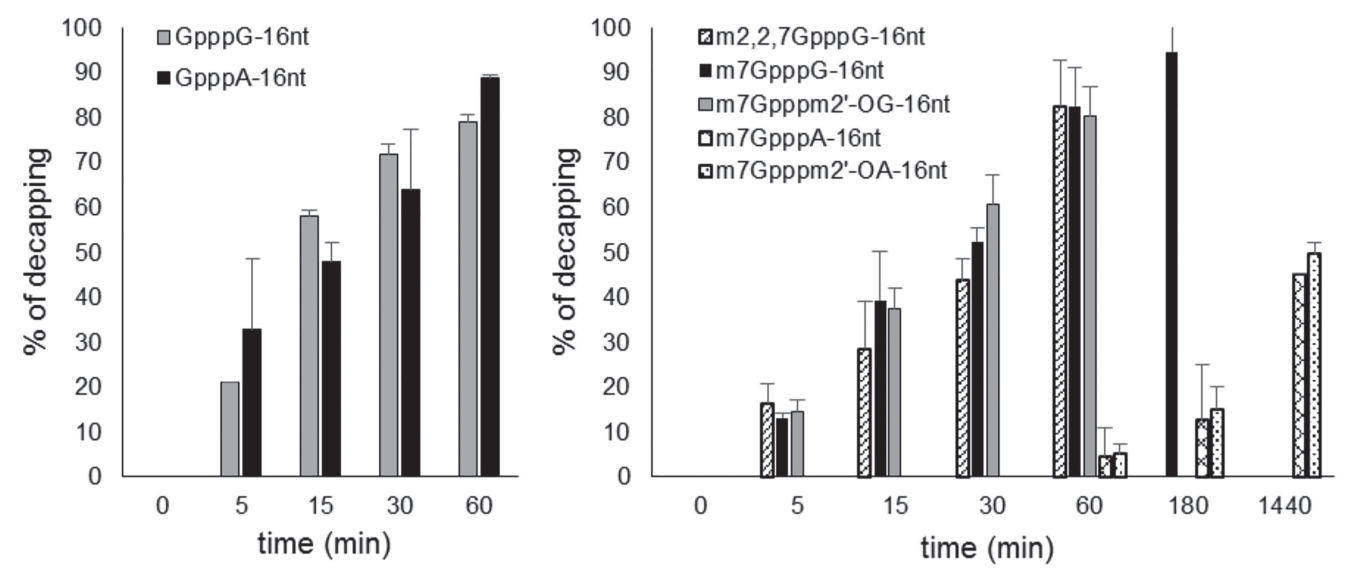

D
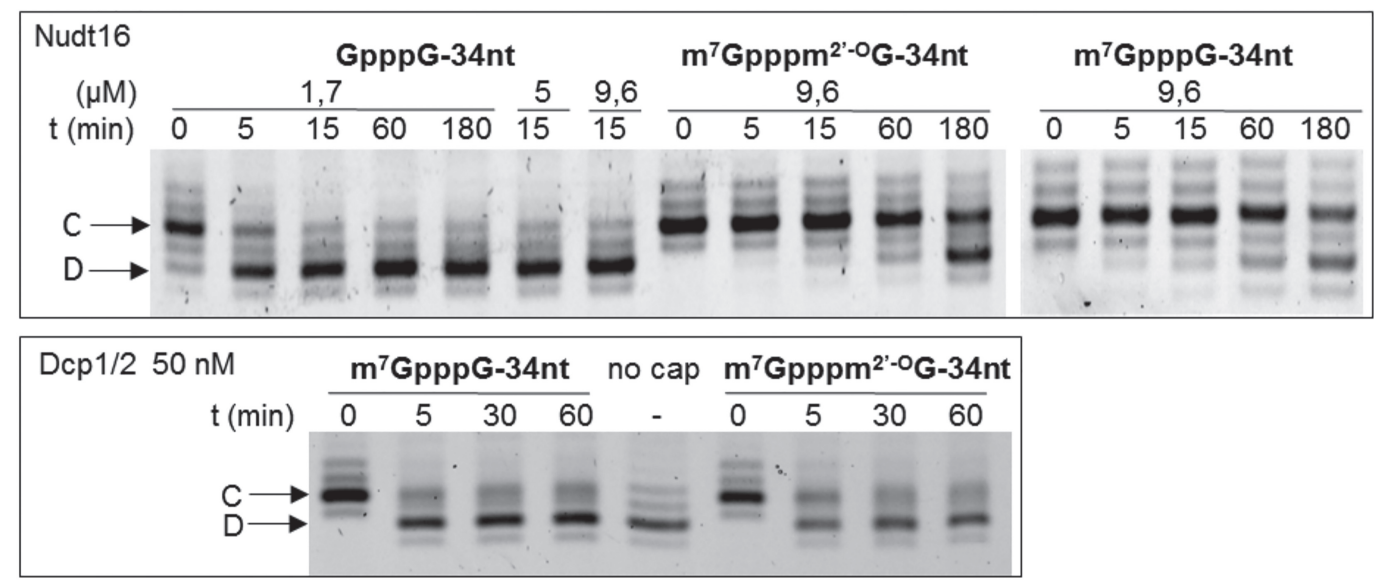

Figure 3. Hydrolysis of capped oligonucleotides by hNudt16. (A) Gel electrophoretic analysis of the progress of the hydrolysis of GpppG-16nt and GpppA-16nt. For comparison, reaction with Dcp1/2 was performed for $\mathrm{m}^{7} \mathrm{GpppG}$-16nt. (B) Gel electrophoretic analysis of 16-nt oligonucleotides bearing different cap structures. $(C)$ Comparison of decapping yield for capped and uncapped 16-nt oligonucleotides. $(D)$ Gel electrophoretic analysis of decapping for methylated and unmethylated 34-nt oligonucleotides. All oligonucleotides were treated with recombinant hNudt 16 at $30^{\circ} \mathrm{C}$ in $50 \mathrm{mM}$ Tris buffer ( $\mathrm{pH}$ 7.9) containing $10 \mathrm{mM} \mathrm{NaCl}, 6 \mathrm{mM} \mathrm{MgCl}_{2}, 10 \mathrm{mM} \mathrm{DTT}$, and $1 \mathrm{mM}$ spermidine. The decapping percentage was calculated as the percent loss in the capped band, normalized by total quantity in the capped and decapped bands. 
Table 2. Hydrolysis of differently capped 16-nt RNAs by recombinant hNudt16

\begin{tabular}{|c|c|c|c|c|c|c|c|c|}
\hline \multirow{2}{*}{$\begin{array}{l}\text { Cap analog at } 5^{\prime} \text { end } \\
\text { of } 16 \text {-nt mRNA }\end{array}$} & \multirow[b]{2}{*}{ Nudt16 } & \multirow[b]{2}{*}{ RNA:Nudt16 } & \multicolumn{6}{|c|}{$\%$ of decapping after indicated time } \\
\hline & & & $5 \mathrm{~min}$ & $15 \min$ & $30 \mathrm{~min}$ & $60 \mathrm{~min}$ & $180 \min$ & $24 \mathrm{~h}$ \\
\hline GpppG $(1 \mu \mathrm{M})$ & $0.9 \mu \mathrm{M}$ & $1: 0.9$ & $21.45 \pm 0.08$ & $58.86 \pm 1.45$ & $72.14 \pm 2.04$ & $79.87 \pm 1.71$ & - & - \\
\hline GpppG $(1 \mu \mathrm{M})$ & $18 \mu \mathrm{M}$ & $1: 18$ & - & 85.80 & - & 85.48 & 86.90 & - \\
\hline $\mathrm{m}^{7} \mathrm{GpppG}(1 \mu \mathrm{M})$ & $18 \mu \mathrm{M}$ & $1: 18$ & $13.09 \pm 1.16$ & $39.40 \pm 10.84$ & $52.55 \pm 2.85$ & $82.63 \pm 8.67$ & $94.76 \pm 6.78$ & - \\
\hline $\mathrm{m}^{7} \mathrm{Gpppm}^{2^{\prime}-\mathrm{O}} \mathrm{G}(1 \mu \mathrm{M})$ & $18 \mu \mathrm{M}$ & $1: 18$ & $14.50 \pm 2.65$ & $37.34 \pm 4.72$ & $60.89 \pm 6.30$ & $80.52 \pm 6.57$ & - & - \\
\hline GpppA $(1 \mu \mathrm{M})$ & $0.9 \mu \mathrm{M}$ & $1: 0.9$ & $32.99 \pm 15.75$ & $48.45 \pm 4.30$ & $63.88 \pm 13.43$ & $89.75 \pm 0.47$ & - & - \\
\hline $\mathrm{m}^{7} \mathrm{GpppA}(1 \mu \mathrm{M})$ & $18 \mu \mathrm{M}$ & $1: 18$ & - & - & - & $4.62 \pm 6.44$ & $12.75 \pm 12.15$ & $45.19 \pm 0.01$ \\
\hline $\mathrm{m}^{7} \mathrm{Gpppm}^{2^{\prime}-O} \mathrm{~A}(1 \mu \mathrm{M})$ & $18 \mu \mathrm{M}$ & $1: 18$ & - & - & - & $5.21 \pm 2.29$ & $15.07 \pm 5.07$ & $49.65 \pm 2.63$ \\
\hline TMG $(1 \mu \mathrm{M})$ & $18 \mu \mathrm{M}$ & $1: 18$ & $16.47 \pm 4.47$ & $28.54 \pm 10.70$ & $43.80 \pm 4.86$ & $82.62 \pm 10.35$ & - & - \\
\hline \multirow{2}{*}{$\begin{array}{l}\text { Cap analog at } 5^{\prime} \text { end } \\
\text { of } 34-n t \text { mRNA }\end{array}$} & & & \multicolumn{6}{|c|}{$\%$ of decapping after indicated time } \\
\hline & Nudt16 & RNA:Nudt16 & $5 \mathrm{~min}$ & $15 \min$ & $60 \mathrm{~min}$ & $180 \mathrm{~min}$ & & \\
\hline GpppG $(0.23 \mu \mathrm{M})$ & $1.7 \mu \mathrm{M}$ & $1: 7.4$ & $46.8 \pm 10.84$ & $70 \pm 5.66$ & $80.69 \pm 2.51$ & $81.44 \pm 2.39$ & & \\
\hline GpppG $(0.23 \mu \mathrm{M})$ & $9.6 \mu \mathrm{M}$ & $1: 42$ & - & $75.30 \pm 3.35$ & - & - & & \\
\hline $\mathrm{m}^{7} \mathrm{GpppG}(0.23 \mu \mathrm{M})$ & $9.6 \mu \mathrm{M}$ & $1: 42$ & $3.2 \pm 1.58$ & $8.77 \pm 1.84$ & $26.25 \pm 5.15$ & $51.85 \pm 4.32$ & & \\
\hline $\begin{array}{c}\mathrm{m}^{7} \mathrm{Gpppm}^{2^{\prime}-\mathrm{O}} \mathrm{G} \\
(0.23 \mu \mathrm{M})\end{array}$ & $9.6 \mu \mathrm{M}$ & $1: 42$ & $1.04 \pm 1.81$ & $8.23 \pm 2.02$ & $27.14 \pm 6.47$ & $43.86 \pm 15.00$ & & \\
\hline
\end{tabular}

The capped RNAs were prepared by in vitro transcription and incubated with hNudt16 during indicated time periods. The reaction mixtures were analyzed on a sequencing gel and stained with fluorescent dye. The decapping percentage was calculated as the percentage loss in the capped band, normalized by total quantity in the capped and decapped bands.

groups in ADP-ribosylated proteins. Considering the structural similarities, the ability of hNudt16 to hydrolyze the cap structure could result from its inability to completely distinguish between various purine diphosphate substructures.

\section{MATERIALS AND METHODS}

\section{Chemical synthesis of cap analogs}

Cap analogs $\left(\mathrm{m}^{7} \mathrm{GpppG}, \quad \mathrm{m}^{7} \mathrm{Gpppm}^{2^{\prime}-\mathrm{O}} \mathrm{G}, \quad \mathrm{m}_{3}^{2,2,7} \mathrm{GpppG}\right.$, $\mathrm{m}^{7} \mathrm{GpppA}$, and $\left.\mathrm{m}^{7} \mathrm{Gpppm}^{2^{\prime}-\mathrm{O}} \mathrm{A}\right)$ and unmethylated dinucleotides (ApppG and GpppG) were synthesized in accordance with the previously described procedures (Darzynkiewicz et al. 1990; Stepinski et al. 1995; Jankowska et al. 1996; Niedzwiecka et al. 2007).

\section{In vitro synthesis of short oligonucleotides and capping reaction}

DNA templates for the generation of short RNAs of 16 and $34 \mathrm{nt}$ were prepared through XhoI or EcoRI cleavage of pSPluc+ plasmid containing either the T7 class III promoter ( $\phi 6.5)$ or the class II promoter ( $\$ 2.5)$. ppp-RNAs were transcribed in vitro with the T7 RNA polymerase in the presence of four nucleotides, as described by Strenkowska et al. (2016). TMG and TMA capped transcripts were obtained by replacing GTP or ATP with $5: 1 \mathrm{~m}_{3}^{2,2,7} \mathrm{GpppG}$ : GTP or $\mathrm{m}_{3}^{2,2,7}$ GpppA:ATP, respectively. $\mathrm{m}^{7} \mathrm{Gppp}$-RNA and Gppp-RNA were prepared through posttranscriptional capping of ppp-RNA with the ScriptCap $\mathrm{m}^{7} \mathrm{G}$ Capping System (CellScript) with or without $S$-adenosylmethionine (SAM) in accordance with the manufacturer's instructions. Briefly, $10 \mu \mathrm{g}$ samples of RNA were heat-denaturated at $65^{\circ} \mathrm{C}$ for $5 \mathrm{~min}$, cooled on ice, and incubated with ScriptCap Buffer in the presence of $1 \mathrm{mM} \mathrm{GTP}, 100 \mu \mathrm{M}$ SAM, 10 U Vaccinia Capping Enzyme, and Script Guard RNase Inhibitor for $3 \mathrm{~h}$ at $37^{\circ} \mathrm{C}$. Cap1-RNA was obtained through simultaneous capping and $2^{\prime}$-O-Methylation from uncapped RNA, using ScriptCap $\mathrm{m}^{7} \mathrm{G}$ Capping System and the ScriptCap 2'-O-Methyltransferase Kit. RNAs were purified using the Oligo Clean-up and Concentration Kit (Norgen Biotek) and analyzed through denaturing PAGE on a $15 \%$ polyacrylamide/7 M urea containing gel. Small amounts of $n+1$ and $n+2$ contaminations originated from the nontemplated addition of nucleotides during in vitro transcription.

\section{Protein expression and purification}

Human Nudt16 (hNudt16, 1-199 aa, MW 22 kDa) was expressed in E. coli Rosetta 2 (DE3) as a C-terminally His-tagged protein using a peET16b_Nudt16 vector, where the coding sequence of Nudt16 was cloned at the Ncol-BamHI restriction sites (verified further through sequencing). A sequence encoding four additional histidine residues introduced immediately after the two terminal histidine residues of Nudt16 resulted in the formation of a $6 \times$ His C-terminal His-tag. The complete protocol of hNudt16 preparation and purification has been presented previously by Wojtczak et al. (2016). Fractions

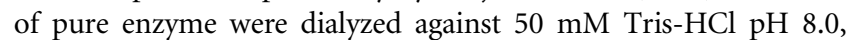
$150 \mathrm{mM} \mathrm{KCl}$, and $20 \%$ glycerol. Aliquots of hNudt 16 were supplemented with $1 \mathrm{mM}$ DTT, frozen in liquid nitrogen, and stored at $-80^{\circ} \mathrm{C}$ until use. 


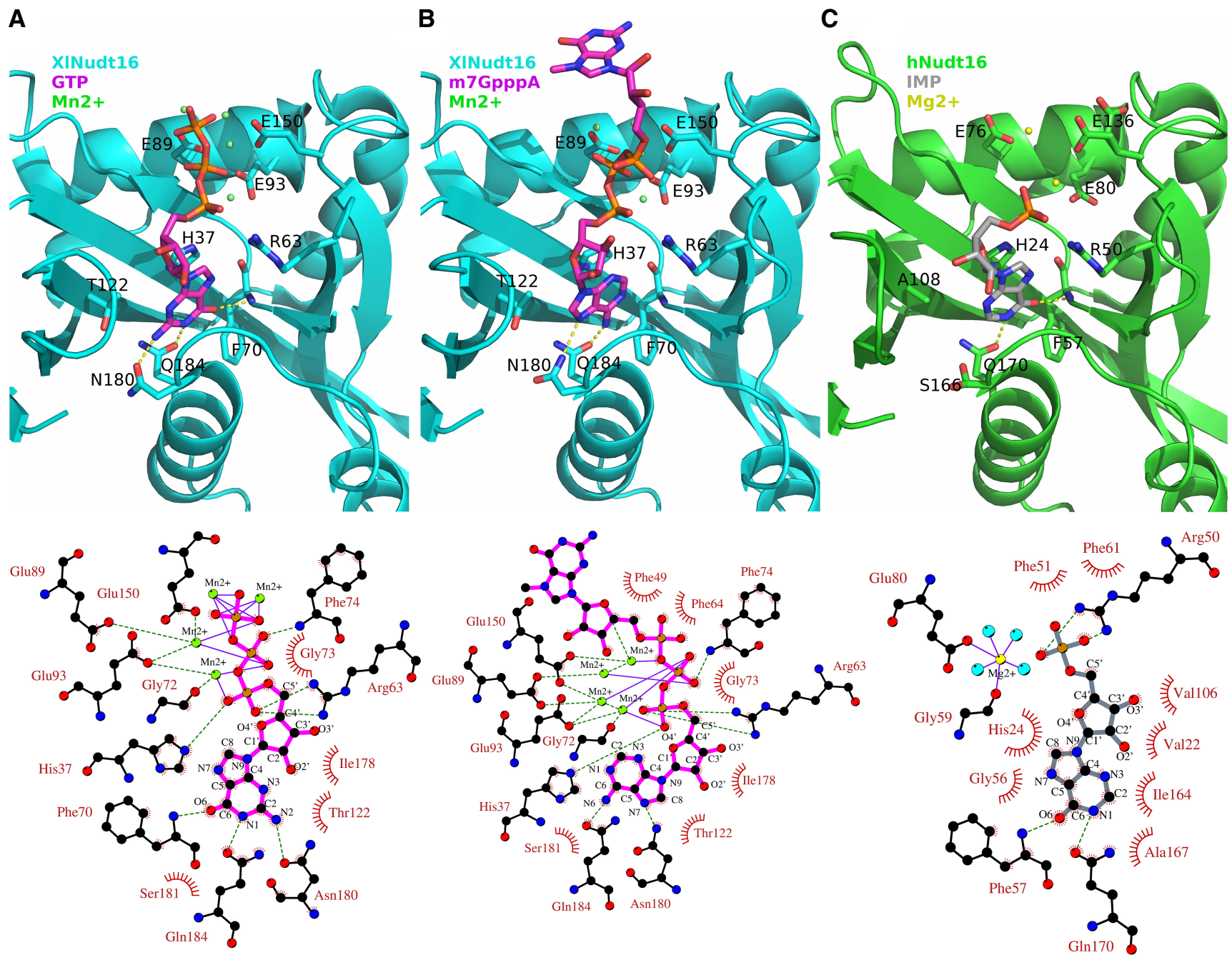

Figure 4. Interactions between Nudt16 and its ligands. (A) (Upper panel) Visualization of the GTP-bound XL Nudt16 active site (PDB 2A8S). Color codes for the protein, ligand, and metal ions are indicated. For clarity, only interactions with the base and selected residues are shown. (Lower panel) Ligplot (Wallace et al. 1995) representation of the structure shown in the upper panel. (B) (Upper panel) Visualization of the XL Nudt16 active site with $\mathrm{m}^{7} \mathrm{GpppA}$. Color codes are the same as those in A. (C) (Upper panel) Visualization of the IMP-bound hNudt16 active site (PDB: 2XSQ). (Lower panel) Ligplot representation of the structure shown in the upper panel.

\section{Decapping assays}

Enzymatic assays for dinucleotides were performed in $40 \mathrm{mM}$ Tris buffer ( $\mathrm{pH}$ 7.9) containing $100 \mathrm{mM} \mathrm{NaCl}, 6 \mathrm{mM} \mathrm{MgCl} 2$ and $2 \mathrm{mM}$ DTT. The concentration of investigated dinucleotides was $15 \mu \mathrm{M}$, and enzyme concentration was $0.9 \mu \mathrm{M}$ for each substrate. Decapping assays for short oligonucleotides were performed in $50 \mathrm{mM}$ Tris buffer ( $\mathrm{pH}$ 7.9) containing $10 \mathrm{mM} \mathrm{NaCl}, 6 \mathrm{mM}$ $\mathrm{MgCl}_{2}, 10 \mathrm{mM} \mathrm{DTT}$, and $1 \mathrm{mM}$ spermidine.

\section{Determination of hydrolytic susceptibility of cap analogs}

To investigate the hydrolytic susceptibility of dinucleotide cap analogs, HPLC analysis was performed. Before each experiment, $1 \mathrm{~mL}$ of buffer solution containing the analyte was incubated at $37^{\circ} \mathrm{C}$ for $10 \mathrm{~min}$. Hydrolysis was initiated through the addition of recombinant hNudt16. After 10, 20, 30, 40, and $60 \mathrm{~min}$ of hydrolysis, $150-\mu \mathrm{L}$ aliquots of the reaction mixture were withdrawn and incubated at $97^{\circ} \mathrm{C}$ during $3 \mathrm{~min}$ to terminate the reaction through heat inactivation of the enzyme. The samples were then subjected to HPLC analysis (Agilent 1200 Series) with a reverse-phase Supelcosil LC-18-T column and UV/VIS-detector. The substrate and products were eluted at $20^{\circ} \mathrm{C}$ with a linear gradient of methanol in $0.1 \mathrm{M} \mathrm{KH}_{2} \mathrm{PO}_{4}$ (from $0 \%$ to $40 \%$ ) over $15 \mathrm{~min}$ at a flow rate of 1.0 $\mathrm{mL} / \mathrm{min}$. Changes in absorbance values at $260 \mathrm{~nm}$ were monitored continuously during the analysis. Hydrolysis products were identified through comparison of their retention times with that of the reference samples. The extent of decapping, determined as the percentage of hydrolyzed substrate, was calculated using area under the chromatographic peak of respective compounds.

To assess the decapping of short oligonucleotides, $20 \mathrm{ng}$ of capped transcripts were digested with different amounts of hNudt16, at 
$30^{\circ} \mathrm{C}$. Reactions were terminated at different time points ( $15 \mathrm{~min}, 30$ min, $1 \mathrm{~h}$, and $3 \mathrm{~h}$ ) by cooling the reaction mixture on ice and adding FORMAzol, followed by denaturation for $3 \mathrm{~min}$ at $55^{\circ} \mathrm{C}$. The substrates and products were separated on an RNA sequencing gel (15\% polyacrylamide, $7 \mathrm{M}$ urea) stained with a fluorescent dye (SYBR Gold Nucleic Acid Gel Stain, Life Technologies) and visualized using a UV-transilluminator (ChemiDoc MP Imaging System, Bio-Rad). The amount of capped substrates and decapped products were determined through densitometric analysis, and the decapping percentage was calculated as the percent loss in the capped band, normalized by total quantity in the capped and decapped bands. Quantity of material in individual bands was analyzed using Image Lab Software (Bio-Rad).

\section{ACKNOWLEDGMENTS}

We thank M. Kiledjian for helpful discussions and critical reading of the manuscript and J. Zuberek and A. Stelmachowska for SpDcp1/2 protein preparation. This study was supported by grants from the Polish National Science Centre (UMO/2013/08/A/NZ1/00866 and DEC-2013/11B/ST5/02226) and the National Centre of Research and Development (STRATEGMED1/235773/19/NCBR/2016).

Received January 15, 2018; accepted February 20, 2018.

\section{REFERENCES}

Arribas-Layton M, Wu D, Lykke-Andersen J, Song H. 2013. Structural and functional control of the eukaryotic mRNA decapping machinery. Biochim Biophys Acta 1829: 580-589.

Bessman MJ, Frick DN, O'Handley SF. 1996. The MutT proteins or "Nudix" hydrolases, a family of versatile, widely distributed, "housecleaning" enzymes. J Biol Chem 271: 25059-25062.

Carreras-Puigvert J, Zitnik M, Jemth AS, Carter M, Unterlass JE, Hallström B, Loseva O, Karem Z, Calderón-Montaño JM, Lindskog C, et al. 2017. A comprehensive structural, biochemical and biological profiling of the human NUDIX hydrolase family. Nat Commun 8: 1541.

Cohen LS, Mikhli C, Jiao X, Kiledjian M, Kunkel G. 2005. Dcp2 decaps $\mathrm{m}_{3}{ }^{2,2,7} \mathrm{GpppN}$ capped RNAs, and its activity is sequence and context dependent. Mol Cell Biol 25: 8779-8791.

Daniels D, Thirawatananond P, Ong SE, Grabelli SB, Leung AKL. 2015. Nudix hydrolases degrade protein-conjugated ADP-ribose. Sci Rep 5: 18271.

Darzynkiewicz E, Stepinski J, Tahara SM, Stolarski R, Ekiel I, Haber D, Neuvonen K, Lehikoinen P, Labádi I, Lönnberg H. 1990. Synthesis, conformation and hydrolytic stability of $\mathrm{P}^{1}, \mathrm{P}^{3}$-dinucleoside triphosphates related to mRNA $5^{\prime}$-cap, and comparative kinetic studies on their nucleoside and nucleoside monophosphate analogues. Nucleosides Nucleotides 9: 599-618.

Deshmukh MV, Jones BN, Quang-Dang DU, Flinders J, Floor SN. 2008. mRNA decapping is promoted by an RNA-binding channel in Dcp2. Mol Cell 29: 324-336.

Franks TM, Lykke-Andersen J. 2008. The control of mRNA decapping and P-body formation. Mol Cell 32: 605-615.

Furuichi Y, Shatkin AJ. 2000. Viral and cellular mRNA capping: past and prospects. Adv Virus Res 55: 135-184.

Ghosh A, Lima CD. 2010. Enzymology of RNA cap synthesis. Wiley Interdiscip Rev RNA 1: 152-172.

Ghosh T, Peterson B, Tomasevic N, Peculis BA. 2004. Xenopus U8 snoRNA binding protein is a conserved nuclear decapping enzyme. Mol Cell 13: 817-828.
Grudzien-Nogalska E, Kiledjian M. 2017. New insights into decapping enzymes and selective mRNA decay. Wiley Interdiscip Rev RNA $\mathbf{8}$. doi: 10.1002/wrna.1379.

Iwasaki S, Takeda A, Motose H, Watanabe Y. 2007. Characterization of Arabidopsis decapping proteins AtDCP1 and AtDCP2, which are essential for post-embryonic development. FEBS Lett 581: 2455-2459.

Iyama T, Abolhassani N, Tsuchimoto D, Nonaka M, Nakabeppu Y. 2010. NUDT16 is a (deoxy)inosine diphosphatase, and its deficiency induces accumulation of single-strand breaks in nuclear DNA and growth arrest. Nucleic Acids Res 38: 4834-4843.

Jankowska M, Stẹpiński J, Stolarski R, Wieczorek Z, Temeriusz A, Haber D, Darżynkiewicz E. 1996. ${ }^{1} \mathrm{H}$ NMR and fluorescence studies of new mRNA 5'-cap analogues. Collect Czech Chem Commun 61: S197-S202.

Lange TS, Borovjagin AV, Gerbi SA. 1998. Nucleolar localization elements in U8 snoRNA differ from sequences required for rRNA processing. RNA 4: 789-800.

Li Y, Song MG, Kiledjian M. 2008. Transcript-specific decapping and regulated stability by the human Dcp2 decapping protein. Mol Cell Biol 28: 939-948.

Li Y, Song M, Kiledjian M. 2011. Differential utilization of decapping enzymes in mammalian mRNA decay pathways. RNA 17: 419-428.

Liu H, Rodgers ND, Jiao X, Kiledjian M. 2002. The scavenger mRNA decapping enzyme DcpS is a member of the HIT family of pyrophosphatases. EMBO J 21: 4699-4708.

Liu SW, Jiao X, Liu H, Gu M, Lima CD, Kiledjian M. 2004. Functional analysis of mRNA scavenger decapping enzymes. RNA 10: $1412-1422$.

Lu G, Zhang J, Li Y, Li Z, Zhang N, Xu X, Wang T, Guan Z, Gao G, Yan J. 2011. hNudt16: a universal decapping enzyme for small nucleolar RNA and cytoplasmic mRNA. Protein Cell 2: 64-73.

McLennan AG. 2006. The Nudix hydrolase superfamily. Cell Mol Life Sci 63: 123-143.

Meyer S, Temme C, Wahle E. 2004. Messenger RNA turnover in eukaryotes: pathways and enzymes. Crit Rev Biochem Mol Biol 39: 197-216.

Mildvan AS, Xia Z, Azurmendi HF, Saraswat V, Legler PM, Massiah MA, Gabelli SB, Bianchet MA, Kang LW, Amzel LM. 2005. Structures and mechanisms of Nudix hydrolases. Arch Biochem Biophys 433: 129-143.

Milligan JF, Groebe DR, Witherell GW, Uhlenbeck OC. 1987. Oligoribonucleotide synthesis using T7 RNA polymerase and synthetic DNA templates. Nucleic Acids Res 15: 8783-8798.

Niedzwiecka A, Stepinski J, Antosiewicz JM, Darzynkiewicz E, Stolarski R. 2007. Biophysical approach to studies of cap-eIF4E interaction by synthetic cap analogs. Methods Enzymol 430: 209245.

Palazzo L, Thomas B, Jemth AS, Colby T, Leidecker O, Feijs KL, Zaja R, Loseva O, Puigvert JC, Matic I, et al. 2015. Processing of protein ADP-ribosylation by Nudix hydrolases. Biochem J 468: 293-301.

Peculis BA, Reynolds K, Cleland M. 2007. Metal determines efficiency and substrate specificity of the nuclear NUDIX decapping proteins X29 and H29K (Nudt16). J Biol Chem 282: 24792-24805.

Picirillo C, Khanna R, Kiledjian M. 2003. Functional characterization of the mammalian mRNA decapping enzyme hDcp2. RNA 9: $1138-1147$.

Scarsdale JN, Peculis BA, Wright HW. 2006. Crystal structures of U8 snoRNA decapping nudix hydrolase, X29, and its metal and cap complex. Structure 14: 331-343.

Schaeffer D, Tsanova B, Barbas A, Reis FP, Dastidar EG, SanchezRotunno M, Arraiano CM, van Hoof A. 2009. The exosome contains domains with specific endoribonuclease, exoribonuclease and cytoplasmic mRNA decay activities. Nat Struct Mol Biol 16: $56-62$.

Song M, Li Y, Kiledjian M. 2010. Multiple mRNA decapping enzymes in mammalian cells. Mol Cell 40: 423-432.

Steiger M, Carr-Schmidt A, Schwartz DC, Kiledjian M, Parker R. 2003. Analysis of recombinant yeast decapping enzyme. RNA 9: 231-238. 


\section{Grzela et al.}

Stepinski J, Bretner M, Jankowska M, Felczak K, Stolarski R, Wieczorek Z, Caipostalcode AL, Rhoads RE, Temeriusz A, Haber D, et al. 1995. Synthesis and properties of $\mathrm{P}^{1}, \mathrm{P}^{2}-, \mathrm{P}^{1}, \mathrm{P}^{3}$, and $\mathrm{P}^{1}, \mathrm{P}^{4}$-dinucleoside di-, tri- and tetraphosphate mRNA $5^{\prime}$-cap analogues. Nucleosides Nucleotides 14: 717-721.

Strenkowska M, Grzela R, Majewski M, Wnek K, Kowalska J, Lukaszewicz M, Zuberek J, Darzynkiewicz E, Kuhn AN, Sahin U, Jemielity J. 2016. Cap analogs modified with 1,2-dithiodiphosphate moiety protect mRNA from decapping and enhance its translational potential. Nucleic Acids Res 44: 9578-9590.

Taylor MJ, Peculis B. 2008. Evolutionary conservation supports ancient origin for Nudt16, a nuclear-localized, RNA-binding, RNA-decapping enzyme. Nucleic Acids Res 36: 6021-6034.

Trésaugues L, Lundbäck T, Welin M, Flodin S, Numan T, Silvander C, Gräslund S, Nordlund P. 2015. Structural basis for the specificity of human NUDT16 and its regulation by inosine monophosphate. PLOS ONE 10: e0131507.

Valkov E, Jonas S, Weichenrieder O. 2017. Mille viae in eukaryotic mRNA decapping. Curr Opin Struct Biol 47: 40-51.

van Dijk E, Cougot N, Meyer S, Wahle E. 2002. Human Dcp2: a catalytically active mRNA decapping enzyme located in specific cytoplasmic structures. $E M B O J$ 21: 6915-6924.

Wallace AC, Laskowski RA, Thornton JM. 1995. LIGPLOT: a program to generate schematic diagrams of protein-ligand interactions. Protein Eng 8: 127-134.

Wojtczak BA, Warminski M, Kowalska J, Lukaszewicz M, Honcharenko M, Smith CIE, Strömberg R, Darzynkiewicz E, Jemielity J. 2016. Clickable trimethylguanosine cap analogs modified within the triphosphate bridge: synthesis, conjugation to RNA and susceptibility to degradation. RSC Advances 6: 8317-8328. 

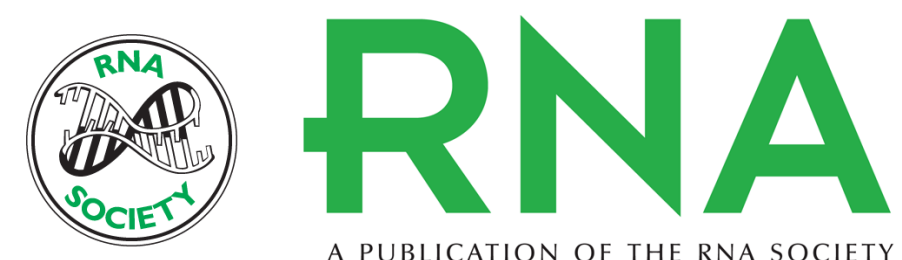

A PUBLICATION OF THE RNA SOCIETY

\section{Hydrolytic activity of human Nudt16 enzyme on dinucleotide cap analogs and short capped oligonucleotides}

Renata Grzela, Karolina Nasilowska, Maciej Lukaszewicz, et al.

RNA 2018 24: 633-642 originally published online February 26, 2018

Access the most recent version at doi:10.1261/rna.065698.118

References This article cites 41 articles, 12 of which can be accessed free at: http://rnajournal.cshlp.org/content/24/5/633.full.html\#ref-list-1

Creative This article is distributed exclusively by the RNA Society for the first 12 months after the Commons full-issue publication date (see http://rnajournal.cshlp.org/site/misc/terms.xhtml). After 12 License months, it is available under a Creative Commons License (Attribution-NonCommercial 4.0 International), as described at http://creativecommons.org/licenses/by-nc/4.0/.

Email Alerting Receive free email alerts when new articles cite this article - sign up in the box at the Service top right corner of the article or click here.

To subscribe to $R N A$ go to:

http://rnajournal.cshlp.org/subscriptions 